\title{
フェノール基含有医薬品と鉄剤との薬物相互作用の予見を目的とした簡易試験法
}

\author{
砂金信義, ${ }^{*}, a$ 吉延悦子, ${ }^{a}$ 村山信子, ${ }^{a}$ 寺脇康文, ${ }^{b}$ 上村直樹, ${ }^{c}$ 宇留野強 ${ }^{a}$
}

\section{Simple Method for Precognition of Drug Interaction between Oral Iron and Phenolic Hydroxyl Group-containing Drugs}

\author{
Nobuyoshi Sunagane, ${ }^{* a}$ Etsuko Yoshinobu, ${ }^{a}$ Nobuko Murayama, ${ }^{a}$ Yasufumi Terawaki, ${ }^{b}$ \\ Naoki KAMIMURA, ${ }^{c}$ and Tsutomu URUNO ${ }^{a}$ \\ Faculty of Pharmaceutical Sciences, Tokyo University of Science (RIKADAI), a 2641 Yamazaki, Noda City 278-8510, \\ Japan, Kirishima Citizens' Pharmacy, ${ }^{b}$ 3-22-17 Chuo, Kirishima City 899-4332, Japan, and \\ Fujimidai Pharmacy,c 2-18-7 Fujimidai, Kunitachi City 186-0003, Japan
}

(Received September 10, 2004; Accepted November 10, 2004)

In the present study, we devised a simple method for detecting the drug interaction between oral iron preparations and phenolic hydroxyl group-containing drugs, using the coloring reaction as indicator, due to the formation of complexes or chelates. In the method, oral iron preparations and test drugs in amounts as much as single dose for adults were added to $10 \mathrm{ml}$ of purified water to make sample suspensions for testing. Thirty minutes after mixing an oral iron suspension and a test drug suspension, the change of color in the mixture was observed macroscopically and graded as 0 to 3 , with a marked color change judged as grade 3 and no color change as grade 0 . Screening of 14 test drugs commonly used orally was carried out. When using sodium ferrous citrate preparations as oral iron, 5 were classified as grade 3,2 as grade 2,4 as grade 1 , and 3 as grade 0 , respectively. To verify usefulness of the method, the interactions suggested by screening were pharmacokinetically assessed by measuring serum concentrations of the drug in mice. When a levodopa or droxidopa preparation, judged as grade 3 in screening, was concomitantly administered with an iron preparation, a significant reduction in bioavailability of the test drug was observed, indicating possible drug interaction between the test drug and oral iron. Combined administration of an acetaminophen preparation, judged as grade 1, and oral iron preparation showed no influence on the bioavailability of the test drug, implying no detectable interactions between them. In conclusion, the simple method devised in the present study is useful for precognition of drug interactions between oral iron preparations and phenolic hydroxyl group-containing drugs, and the drugs with a higher grade in screening may induce drug interactions with oral iron.

Key words_ - drug interaction; oral iron; phenolic drug; levodopa; droxidopa

序論

今日の薬物療法ではもつぱら多剤併用療法がとら れている．薬物の併用により薬物相互作用が発現 し，薬物療法が障害されることが少なくなく，多剤 併用療法では薬物相互作用の回避が重要な要件とな る. 薬物相互作用の回避は, 医薬品添付文書中の情 報を手掛かりに実施されているが，添付文書中の相 互作用に関する情報は十分ではなく，未記載の相互 作用も多く発現している. 薬物相互作用の発現を予

$a$ 東京理科大学薬学部臨床薬学研究室, $b$ 霧島市民薬局, $c$ 富士見台調剂薬局

e-mail: sunagane@rs.noda.tus.ac.jp
測する手段の開発は，未知の薬物相互作用の回避を 可能にするものであり，適正な薬物療法を行う上で 有用であると考えられる.

鉄剂は種々の薬物と錯化合物を形成して薬物動態 学的相互作用を発現させる. 例えば，テトラサイク リン系抗生物質やニューキノロン系抗菌薬などを鉄 剂と併用すると，キレートが形成され，消化管吸収 が阻害されることが知られている. 1,2) フェノール性 水酸基含有化合物は，鉄イオンと錯化合物を形成す ることが知られており，フェノール性水酸基含有医 薬品は，鉄剤との併用により錯化合物を形成し，薬 物相互作用を発現する恐れがある。しかし，その情 報は少ない. 
フェノール性水酸基含有化合物と鉄剂の錯体形成 は，呈色反応として検出されることが知られてい る.この呈色反応は，フェノール性水酸基含有医薬 品と経口鉄剤についても錯体形成の指標となるもの と予想される. したがって，この色調変化を指標と してフェノール性水酸基含有医薬品と鉄剂との薬物 相互作用の有無を検索することが可能であると考え られる。

本研究では, 経口鉄剂とフェノール性水酸基含有 医薬品の併用による相互作用発現の可能性を検出す るスクリーニング法として，フェノール性水酸基含 有化合物と鉄との錯化合物形成に基づく色調变化を 指標とした簡易スクリーニング法を提示し，フェ ノール性水酸基含有医薬品のうち経口剂として比較 的繁用される医薬品 14 種について市販製剂を用い て簡易試験法を実施した。ささに，簡易スクリーニ ング法で検出された薬物について，マウスにおける 血中薬物濃度を測定して薬物相互作用の発現を評価 して，簡易試験法の有用性を検討した.

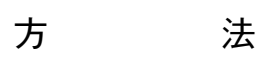

\section{1. 簡易試験法}

1-1. 手順 (1)被験医薬品の剂形が散剤, 顆粒 剂はそのままで, カプセル剂は内容物のみ, 錠剂な どの固形製剤は乳鉢を用いて粉砕して試料とした.

(2)各試料を成人 1 回服用相当量をとり, 容量 $15 \mathrm{ml}$ の試験管に入れ， $10 \mathrm{ml}$ の精製水を加え，よく振と うし, 試験液を調製した。この際, 試料の溶解性は 考慮に入れずに，不溶成分を含むものについては懸 濁状態で用いた。鉄剤についても同様に調製した.

(3) 2 つ試験液（試料及びに鉄剤）を $5 \mathrm{ml}$ づつ分 取して, 別の試験管中で混合し，よく振とうした.

残りの各試験液にはそれぞれ $5 \mathrm{ml}$ の精製水を加え 対照液とした。

(4)試験液の混合後 30 分間に渡り, 混合した試験液 と対照液の色調を肉眼で観察し，その色調変化を 4 段階のグレード（グレード $0-3 ）$ に分類し評価し た.

グレード 0：呈色反応がみられなかったもの

グレード 1: 色調変化の程度が微弱なもの

グレード 2 : 徐々に進行する色調変化がみられたも の

グレード $3:$ 混合直後に著しい色調変化がみられた
もの

1-2. 簡易試験法に用いた被験医薬品簡易試 験法には以下の 14 種のフェノール性水酸基含有医 薬品及びテトラサイクリンの市販製剤を用いた.

アセトアミノフェン（カロナール，昭和薬化工）, アモキシシリン (サワシリン, 藤沢), 塩酸イソプ レナリン (イソメニール, 科研), 塩酸エチレフリ ン（エホチール，日本ベーリンガー），塩酸ラベタ ロール（トランデート，グラクソ・スミスクライ ン), サラゾスルファピリジン（サラゾピリン，三 菱), ドロキシドパ (ドプス, 住友), ヒメクロモン (ヒメコール, キッセイ), フロプロピオン（コスパ ノン, エーザイ), メサラジン (ペンタサ, 杏林),

メチルドパ（アルドメット, 万有), 硫酸サルブタ モール (ベネトリン, 三共), 硫酸テルブタリン (ブリカニール, アストラゼネカ), レボドパ（マド パー：ベンセラジド合剤, 中外, メネシット：カル ビドパ合剂，万有）及び塩酸デメチルクロルテトラ サイクリン(レダマイシン, 日本ワイスレダリー).

また，鉄剂としてはクエン酸第一鉄ナトリウム （フェロミア顆粒，エーザイ）及び硫酸鉄（フェロ・ グラデュメット錠，大日本）を用いたが，硫酸鉄製 剂は着色してあり, 色調判定の障害になると考えら れたので, 試薬（硫酸鉄 II 7 水和物）についても検 討した.

\section{2. 薬物血中濃度測定}

2-1. 実験動物 4 週齢の ddY 系雄性マウスを 用いた。実験開始の 2 時間前に絶食したマウスを被 験医薬品の単独投与群と被験医薬品と鉄剂の混合投 与群の 2 群に無作為に分け，各群についてそれぞれ の測定時間毎に 5 匹ずつ用いた.

2-2. 経口投与 被験医薬品は, 錠剤について は粉砕後, カプセルは内容物を, 顆粒剂, 粉末はそ のまま，水性あるいは 3\% CMC 懸濁液として，マ ウス体重 $10 \mathrm{~g}$ 当たり $0.1 \mathrm{ml}$ を経口投与した。被験 医薬品の投与量は，それぞれのヒトにおける成人 1 回服用量を標準体重（kg）で除した值を基に体重 当たりの投与量を換算し，これを基準投与量として 定量薬物の HPLCによる検出限界を考慮してマウ ス投与量を算出した. レボドパ，ドロキシドパ，ア セトアミノフェンについては, 原薬物量としてそれ ぞれ $50 \mathrm{mg} / \mathrm{kg}, 30 \mathrm{mg} / \mathrm{kg}, 50 \mathrm{mg} / \mathrm{kg}$ とした. 併用 鉄剂の投与量は, 定量薬物と鉄剂との用量比がそれ 
ぞれの薬物の成人 1 回投与量の比に一致するように 調整して投与した.

2-3. 血漿サンプル調製法薬物投与後の各測 定時間にエーテル麻酔下にマウスを開腹し, 腹大静 脈より採血した。レボドパ（マドパー；ベンセラジ ド合剂）投与群では投与後 10，15，20，60 分時, ドロキシドパ（ドプス）投与群では，10，20，40， 60, 90 分時, アセトアミノフェン（カロナール） 投与群では， $5 ， 10 ， 15 ， 30 ， 40$ 分時にそれぞれ採 血した。採取した血液から調製した血漿あるいは血 清に 2-3 倍量の $0.5 \mathrm{~mol} / 1$ 過塩素酸を加え, 遠心分 離して除タンパクし，さらにその上清をメンブラン フィルターでろ過して HPLC 用サンプルとした. なお，アセトアミノフェンの定量に用いた血清には 内部標準物質としてテオフィリンを $10 \mu \mathrm{g} / \mathrm{ml}$ あら かじめ加えた。

\section{2-4. HPLC 分析 HPLC 分析には, HPLC} 装置（LC-10AT，島津製作所）, ODS カラム (Senshu Pak) を用いた.

レボドパ，ドロキシドパの血中濃度の測定は, Betto らの手法) に準じて, 移動相には OSA（2× $\left.10^{-4} \mathrm{~mol} / \mathrm{l}\right)$, EDTA $2 \mathrm{Na}\left(3 \times 10^{-4} \mathrm{~mol} / \mathrm{l}\right)$ を含 み, 酢酸で $\mathrm{pH} 3$ に調整した $0.025 \mathrm{~mol} / 1$ 酢酸ナト リウム：メタノール $(92: 8)$ 混合溶液を用い，0.9 $\mathrm{ml} / \mathrm{min}$ の速度で流出させた。 測定薬物の検出は,
分光蛍光光度計（FP-920, 日本分光）を用い, 励 起波長 $282 \mathrm{~nm}$, 蛍光波長 $322 \mathrm{~nm}$ の条件で行った.

アセトアミノフェンの血中濃度は, Brunner らの 方法 ${ }^{4)}$ に準じて，移動相にはリン酸で $\mathrm{pH} 2.2$ に調 整した $0.05 \mathrm{mmol} / 1$ 硫酸ナトリウム : アセトニトリ ル（95：5）混合溶液を用い， $1.0 \mathrm{ml} / \mathrm{min}$ の速度で 流出させた. アセトアミノフェンの検出は, 紫外線 分光光度計（SPD-10，島津製作所）を用い，波長 $254 \mathrm{~nm}$ における光度を測定して行った.

\section{2-5. 統計処理 デー夕は, 平均值士標準誤} 差（S.E.）で示した. 単独投与群と混合投与群の各 測定時における血中レボドパ，及びアセトアミノフ エン濃度について平均值の差を Student の $t$-test を 用いて検定し， $p<0.05$ をもつて有意とした。ま た, 定量薬物の血中濃度曲線下面積 (AUC) は, 測定時間を底辺とする台形法を用いて求めた。

結果

1. 簡易スクリーニング まず本簡易試験法の 妥当性を検討する目的で, 医薬品添付文書中で鉄剂 との併用によりキレート形成による相互作用発現の 可能性が記載されているテトラサイクリン（レダマ イシン）製剤及び茶について本簡易試験法を用いて スクリーニングを行った. クエン酸第一鉄ナトリウ ム製剤（フェロミア）を混合したときの反応例を

Table 1. Grades of Coloring Reaction after Mixing Oral Iron Suspension with Test Drug Suspension

\begin{tabular}{|c|c|c|}
\hline 判 定 & クエン酸第一鉄ナトリウム併用時 & 硫酸鉄併用時 \\
\hline Grade 3 & $\begin{array}{l}\text { 塩酸イソプレナリン（緑色） } \\
\text { ドロキシドパ（黒紫色） } \\
\text { メサラジン（濃緑色） } \\
\text { メチルドパ（黒紫色） } \\
\text { レボドパ（黒紫色） }\end{array}$ & $\begin{array}{l}\text { 塩酸イソプレナリン（青色） } \\
\text { 塩酸ラベタロール（桃色） } \\
\text { ドロキシドパ（青灰色） } \\
\text { メサラジン（赤紫色） } \\
\text { メチルドパ（黒紫色） } \\
\text { レボドパ（黒紫色） }\end{array}$ \\
\hline Grade 2 & $\begin{array}{l}\text { 塩酸ラベタロール（緑褐色） } \\
\text { フロプロピオン（濃緑色） }\end{array}$ & フロプロピオン（橙色） \\
\hline Grade 1 & $\begin{array}{l}\text { アセトアミノフェン（上面黒色） } \\
\text { 塩酸エチレフリン（粒子析出） } \\
\text { サラゾスルファピリジン（黄褐色） } \\
\text { ヒメクロモン（緑色） }\end{array}$ & $\begin{array}{l}\text { 塩酸エチレフリン（淡黄色） } \\
\text { サラゾスルファピリジン（橙色） } \\
\text { ヒメクロモン（色調増加） }\end{array}$ \\
\hline Grade 0 & $\begin{array}{l}\text { アモキシシリン } \\
\text { 硫酸サルブタモール } \\
\text { 硫酸テルブタリン }\end{array}$ & $\begin{array}{l}\text { アセトアミノフェン } \\
\text { アモキシシリン } \\
\text { 硫酸サルブタモール } \\
\text { 硫酸テルブタリン }\end{array}$ \\
\hline
\end{tabular}

カッコ内は判定時の色調を示す. 
A

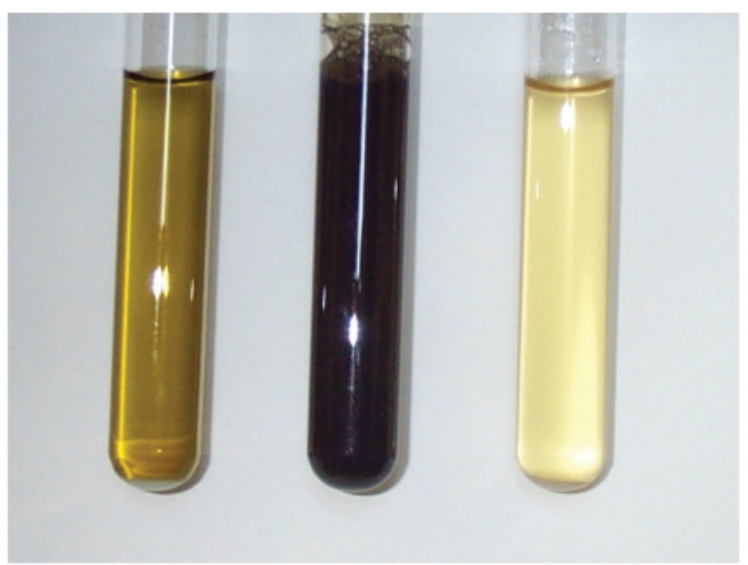

B

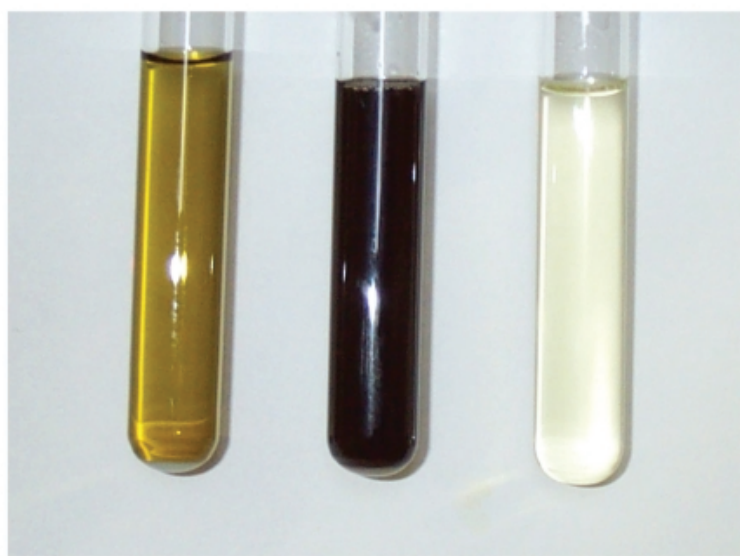

Fig. 1. Coloring Reaction after Mixing Oral Iron (Sodium Ferrous Citrate) Preparation with Tetracycline (Demethylchlortetracycline Hydrochloride) Preparation (A) or Tea (B)

Left: oral iron suspension, middle: mixed suspension, right: tetracycline suspension (A) or tea (B).

Fig. 1 に例示したが，テトラサイクリン溶液及び茶 を鉄剂溶液と混合すると直ちに顕著な色調変化を発 現し，本スクリーニングの基準ではグレード 3 に判 定された.

分子中にフェノール性水酸基を含有する医薬品で 経口用剂として用いられるもののうち，臨床上繁用 されると考えられた 14 種の医薬品について簡易ス クリーニングを行った．鉄剤としてクエン酸第一鉄 ナトリウム（フェロミア）を用いたときの結果を Table 1 に要約して示した. 被験医薬品のうちアモ キシシリン，硫酸サルブタモール，硫酸テルブタリ ンの 3 種以外は，その程度に差は認められるものの
A

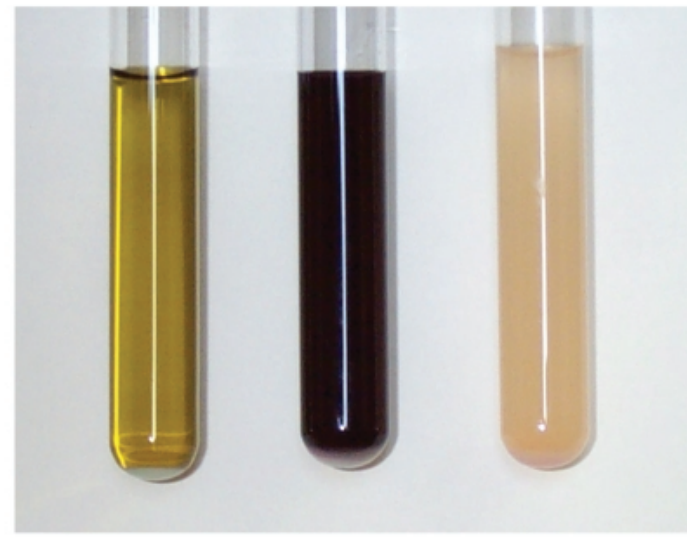

B

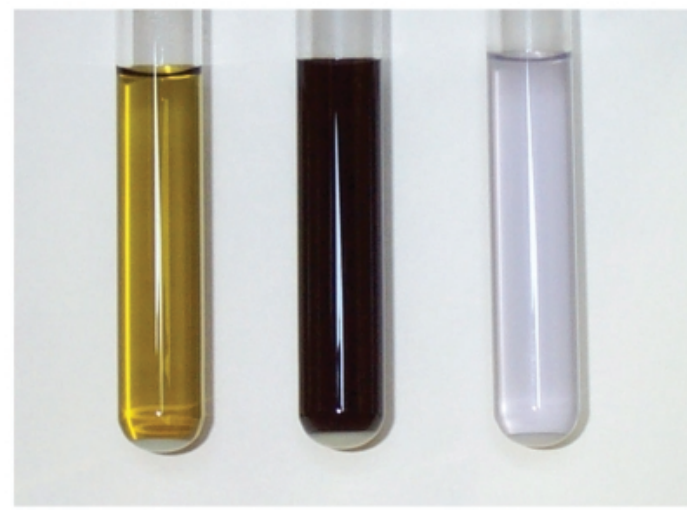

C

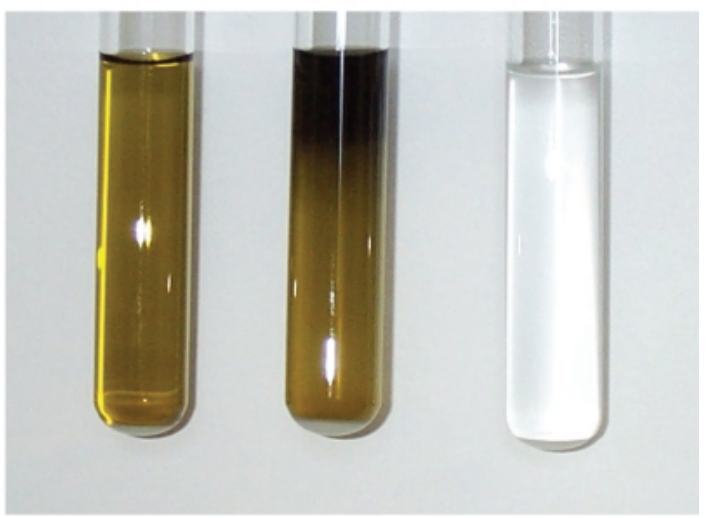

Fig. 2. Coloring Reaction after Mixing Oral Iron (Sodium Ferrous Citrate) Preparation with Levodopa Preparation (A) , Droxidopa Preparation (B) or Acetaminophen Preparation $(\mathrm{C})$

Left: oral iron suspension, middle: mixed suspension, right: test drug suspension. 
本簡易試験法に陽性を示し，このうち，レボドパ (ベンセラジド合剤, カルビドパ合剤), メチルド パ, ドロキシドパ, メサラジン，イソプレナリンの 5 種は, 最も顕著な色調変化を示すグレード 3 に, 塩酸ラベタロール, フロプロピオンの 2 種がグレー ド 2 に, 残り 4 種（アセトアミノフェン, 塩酸エチ レフリン，サラゾスルファピリジン，ヒメクロモ ン）はグレード 1 にそれぞれ区分された. Figure 2 に, グレード 3 を示したレボドパ (ベンセラジド合 剂)，ドロキシドパ及びグレード 1 を示したアセト アミノフェンの反応結果を例示した。鉄剤として硫 酸鉄を用いた実験では製剤及び試薬を用いたが，製 剤を用いると錠剂の色素が溶出して試験液が赤色に 着色した。製剂を用いた場合でもスクリーニングは 可能であったが，色調変化を正確に判定するために 試薬を用いたときの結果を表示した（Table 1)。硫 酸鉄ではクエン酸第一鉄ナトリウムを用いた場合に 比べて, 多くの被験医薬品で呈色の色調が異なるこ とや，判定グレードに若干の差が認められるものが あったが，スクリーニングの判定結果はおおむね一 致した.

2. 血中薬物濃度 レボドパ $(50 \mathrm{mg} / \mathrm{kg})$ を単 独投与すると，血中レボドパ濃度は，投与後 15 分 時に最大に達し， 60 分時にも高レベルな血中濃度 が維持されていた.レボドパにクエン酸第一鉄ナト リウムを混合して投与すると，レボドパの時間一血 中濃度曲線は, 単独投与時の曲線に比して下方に移 動し，20 分時のレボドパ血中濃度は鉄剤併用によ り有意に低下した.レボドパのマウスにおける血中 薬物動態のパラメーターを Table 2 に示したが, レ ボドパ単独投与群の AUC に比してクエン酸第一鉄 ナトリウム混合投与群の AUC は 22\%低下した.

ドロキシドパ（30 $\mathrm{mg} / \mathrm{kg} ）$ を単独投与すると, 血中ドロキシドパ濃度は, 投与後 40 分時に最大に 達し, 90 分時にも高レベルな血中ドロキシドパ濃 度が維持されていた。ドロキシドパにクエン酸第一 鉄ナトリウムを混合して投与すると, ドロキシドパ の時間一血中濃度曲線は，下方に大きく移動し，40 分時, 60 分時のドロキシドパ血中濃度は鉄剂併用 により有意に低下した. ドロキシドパの血中薬物動 態を Table 3 に示したが, AUC 值は, 単独投与群 に比して鉄剤投与群では $42 \%$ 低下した。

アセトアミノフェン（50 mg/ $\mathrm{kg} ）$ を単独投与す
Table 2. Pharmacokinetic Parameters of Levodopa in Mice after Ingestion of Levodopa Preparation with or without Oral Iron (Sodium Ferrous Citrate) Preparation

\begin{tabular}{lcc}
\hline \hline & 単独投与群 & $\begin{array}{c}\text { クエン酸第一鉄 } \\
\text { ナトリウム併用群 }\end{array}$ \\
\hline $\mathrm{T}_{\max }(\mathrm{min})$ & 15 & 15 \\
\hline $\mathrm{C} 20 \mathrm{~min}(\mu \mathrm{g} / \mathrm{ml})$ & $14.9 \pm 0.7(n=5)$ & $10.1 \pm 1.1^{*}(n=5)$ \\
\hline $\begin{array}{c}\mathrm{AUC} \\
\left(\mu \mathrm{g} \cdot 60 \mathrm{ml}^{-1} / \mathrm{min}\right)\end{array}$ & 732.1 & 569.9 \\
\hline$*: p<0.05$ & &
\end{tabular}

Table 3. Pharmacokinetic Parameters of Droxidopa in Mice after Ingestion of Droxidopa Preparation with or without Oral Iron (Sodium Ferrous Citrate) Preparation

\begin{tabular}{lcc}
\hline \hline & 単独投与群 & $\begin{array}{c}\text { クエン酸第一鉄 } \\
\text { ナトリウム併用群 }\end{array}$ \\
\hline $\mathrm{T}_{\max }(\mathrm{min})$ & 40 & 20 \\
\hline $\mathrm{C} 40 \mathrm{~min}(\mu \mathrm{g} / \mathrm{ml})$ & $4.9 \pm 0.5(n=5)$ & $2.3 \pm 0.3^{*}(n=5)$ \\
\hline $\mathrm{C} 60 \mathrm{~min}(\mu \mathrm{g} / \mathrm{ml})$ & $4.4 \pm 0.3(n=5)$ & $1.7 \pm 0.1^{*}(n=5)$ \\
\hline $\left.\begin{array}{c}\mathrm{AUC} \\
(\mu \mathrm{g} \cdot 90\end{array} \mathrm{ml}^{-1} / \mathrm{min}\right)$ & 342.2 & 198.9 \\
\hline$*: p<0.05$ & &
\end{tabular}

Table 4. Pharmacokinetic Parameters of Acetaminophen in Mice after Ingestion of Acetaminophen Preparation with or without Oral Iron (Sodium Ferrous Citrate) Preparation

\begin{tabular}{lcc}
\hline \hline & 単独投与群 & $\begin{array}{c}\text { クエン酸第一鉄 } \\
\text { ナトリウム併用群 }\end{array}$ \\
\hline $\mathrm{T}_{\max }(\mathrm{min})$ & 5 & 5 \\
\hline $\mathrm{C} 5 \mathrm{~min}(\mu \mathrm{g} / \mathrm{ml})$ & $12.8 \pm 0.5(n=5)$ & $16.1 \pm 3.3(n=5)$ \\
\hline $\begin{array}{c}\mathrm{AUC} C_{0 \rightarrow 40} \\
\left(\mu \mathrm{g} \cdot \mathrm{ml}^{-1} / \mathrm{min}\right)\end{array}$ & 290.9 & 314.5 \\
\hline
\end{tabular}

ると，アセトアミノフェンの血中濃度は，投与後 5 分時に最高血中濃度に達し，測定した 40 分時まで 時間の経過につれて低下した。アセトアミノフェン とクエン酸第一鉄ナトリウム混合投与群では，投与 後 5 分時のアセトアミノフェンの血中濃度は単独投 与群における值に比して増大傾向を示したが，その 後のアセトアミノフェンの時間一血中濃度曲線は単 独投与群の曲線とほぼ一致した。 アセトアミノフェ ンの AUC 值は単独投与群と混合投与群で差は認め られなかった (Table 4).

\section{考察}

鉄はフェノール性化合物と錯化合物を形成して呈 
色するので，その検出試薬として用いられる．本研 究で提唱する簡易試験法は，この呈色反応を鉄剤と 医薬品との錯化合物形成の検出に応用したものであ る. 鉄剤の添付文書中でキレート形成による相互作 用発現が示唆されているテトラサイクリン及び茶に ついて，本簡易試験法を適用したところ，グレード 3 に相当する陽性反応を示した（Fig. 1)。この結果 は，本簡易試験法により錯化合物形成の検出が可能 であることを示している.

本簡易試験法を用いたスクリーニングでは被験医 薬品 14 種中 11 種が陽性と判定された。したがつ て，反応陽性を示した医薬品は，鉄剂との併用によ り錯化合物を形成したものと解釈できる，反応陽性 11 種中, クエン酸第一鉄ナトリウムを鉄剤として 用いた時には 5 種，硫酸鉄を用いた時には 6 種が顕 著な反応を示すグレード 3 に区分されたが，このう ち, 塩酸イソプレナリン, ドロキシドパ, メチルド パ，レボドパは分子中にカテコール基を有してお り，この置換基を有する医薬品は特に反応性が高い と言えた. カテコール基含有化合物は鉄イオンとキ レートを形成することが知られており，本試験法に おける上記 4 種の医薬品の呈色反応もキレート形成 によるものと予想される.

錯化合物の形成は, 薬物の消化管吸収に影響を及 ぼすと予想され，本結果から，本スクリーニングに 陽性を示した医薬品は鉄剂との併用により錯化合物 形成を介する相互作用を発現する可能性が示唆され る. 中でも顕著な反応を示すグレード 3 に区分され た医薬品は，鉄剂との併用により薬物相互作用を発 現する可能性は大きいと予想される。事実, 本スク リーニングでグレード 3 に判定されたレボドパとメ チルドパについては，鉄剤併用によりキレート形成 による消化管吸収が阻害され，血中濃度が低下され ることが報告されている. ${ }^{5,6)}$ また，グレード 3 に相 当する陽性反応を示したテトラサイクリン類も鉄剤 との併用により，消化管吸収の阻害に基づく相互作 用を発現させることが報告されている. 1,2) しかし， レボドパ，メチルドパ以外のスクリーニングに陽性 を示した医薬品については, 鉄との相互作用発現の 可能性を示唆する文献が検索されず，本スクリーニ ング結果は，相互作用の発現を予見する上で重要な 手掛かりを与えるものと考えられる.

本研究ではレボドパ製剤として，マドパーとメネ
シットを用いたが，両製剤はそれぞれベンセラジド とカルビドパの合剤であり，これら合剤薬物は分子 中にフェノール基（ピロガロール基及びカテコール 基）を有するので，簡易試験法の結果は，それらに よる反応の結果であるとも言える。しかし，結果に は示していないが L-ドパ試薬を単独で用いた場合 にも，グレード 3 に相当する反応を示したことで, この簡易試験法の結果をレボドパによる反応である ことを確認した。

貧血の治療に用いられる鉄剂としては多くの鉄塩 が用いられている。本研究ではクエン酸第一鉄ナト リウムと硫酸鉄を用いてスクリーニングを行った が，両鉄塩でおおむね一致した結果が得られた。し たがって，本簡易試験法は，鉄剤の種類に関係なく 反応が観察できるものと考えられる.

本研究では，さらに簡易試験法に陽性を示した医 薬品についてマウスにおける血中薬物濃度を測定し て本試験法の妥当性を薬物動態学的に評価した。簡 易試験法でグレード 3 に区分されたレボドパ製剤 （マドパー）とドロキシドパ製剤では，クエン酸第 一鉄ナトリウム製剂と混合投与すると，単独投与時 に比してレボドパ及びドロキシドパの最高血中濃度 及び AUC 值が低下し, 両薬物のバイオアベイラビ リティの低下が観察され, 両製剤では, 薬物動態学 的に鉄剂との相互作用の発現が確認された. 以上の ように，本簡易試験法によるスクリーニングで陽性 反応を示す医薬品のうち，少なくとも顕著な反応を 示し高い判定グレードの医薬品については鉄剂併用 により薬物相互作用の発現が薬物動態学的にも検出 され，本簡易試験法が，鉄剂との相互作用発現を検 出するスクリーニングに有用であることが示唆され た。一方，簡易試験法でグレード 1 に区分されたア セトアミノフェン製剂は，クエン酸第一鉄ナトリウ ムとの併用によってバイオアベイラビリティに変化 は検出されず，鉄剂併用による薬物相互作用の発現 は確認されなかった。したがって，本簡易試験法に おいて判定グレードが低い医薬品では鉄剂併用によ る相互作用発現の可能性は小さいと予想され，本簡 易試験法の判定グレードが相互作用発現を予測する 指標となるものと考えられる.

レボドパ製剂と鉄剤との相互作用に関して, Campbell らは硫酸鉄製剤の併用によりパーキンソ ン病患者におけるレボドパ血中濃度が低下し, 臨床 
効果が減弱される可能性のあることを既に報告して

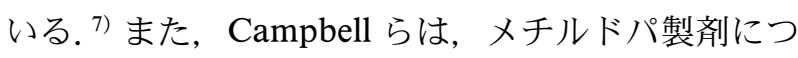
いても鉄剂との併用により相互作用が発現し，降圧 効果が減弱されることを報告している。 ${ }^{8)}$ 一方, 本 研究で検討したドロキシドパ製剤については，これ まで鉄剤との併用による薬物相互作用の発現に関す る報告はない.

医薬品の相互作用については添付文書中に記載さ れるが，レボドパ製剤の鉄剂との相互作用は，レボ ドパ製剤のうち一部の製剤（ベンセラジド合剤，カ ルビドパ合剤）については最近改正（2003 年）の 添付文書中9,10)に，また，メチルドパについては前

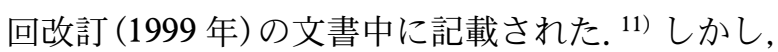
本研究で示唆されたドロキシドパ製剤については, 鉄剂との相互作用の添付文書への記載はない。した がって，ドロキシドパ製剤が鉄剂との薬物相互作用 に発現の可能性を示した本研究結果は, 臨床的にも 意味があるものであると考えられる。

結論として，フェノール基と鉄との錯化合物形成 による呈色反応を利用した本簡易試験法は, フェ ノール性水酸基含有医薬品と鉄剂との相互作用の予 見に有用であり，薬物相互作用を回避するための情 報提供の手段となるものと考えられる.

謝辞 ドロキシドパの標準品を提供頂いた住友 製薬に感謝申し上げます。

\section{REFERENCES}

1) Stockley I. H., "Drug Interaction," 2nd ed. Blackwell Sci. Publ., Oxford, 1991.

2) Hansten P. D., "Drug Interaction," 5th ed., supervised for translation by Sekiguchi K., Katagiri S., Shimada H., Suzuki E., Suguro N., Hayashida A., Ishiyaku Publishers, Inc., Tokyo, 1987.

3) Betto P., Ricciarello G., Giambenedetti M., Lucarelli C., J. Chromatogr., 459, 341-349 (1988) .

4) Brunner L. J., Bai S., J. Chromatogr., 732, 323-329 (1999).

5) Campbell N. R. C., Hasinoff B., Clin. Pharmacol. Ther., 45, 220-225 (1989).

6) Campbell N. R. C., Campbell R. R. A., Hasinoff B. B., Clin. Invest. Med., 13, 329332 (1990).

7) Campbell N. R. C., Rankine D., Goodridge A. E., Hasinoff B. B., Kara M., Br. J. Clin. Pharmacol., 30, 599-605 (1990).

8) Campbell N. R. C., Paddock V., Sundaram R., Clin. Pharmacol. Ther., 37, 308-315 (1988).

9) Attached document 「Madopar $\left.{ }^{\circledR}\right\rfloor\langle$ http:// www.info.pmda.go.jp $\rangle$.

10) Attached document $\left\lceil\right.$ Menesit ${ }^{\circledR}$ Tab.」〈http:// www.info.pmda.go.jp $\rangle$.

11) Attached document $\left\lceil\right.$ Aldomet ${ }^{\circledR}$ Tab.」〈http:// www.info.pmda.go.jp $\rangle$. 